\title{
Facebook as a Venue for Learning Writing Skills in English: A Survey Based on an ELT Experiment
}

\section{Dilini Jayarathna}

\section{Abstract}

Facebook is a website that allows users who sign-up for free profiles, to connect online with friends, work colleagues, or strangers while providing prospects to share pictures, music, videos, and articles, as well as their thoughts and opinions with people they prefer. Considering its capacity to build networks out of various types of interest groups among young people, this study strives to investigate the utilization of a Facebook group as a platform for teaching and learning English as a Second Language (ESL). In the present experiment, a sample of 30 intermediate-level ESL learners joined with a Facebook group under the banner "Time for Writing" to learn paragraph writing in English for a period of six weeks. Throughout the period, the teacher presented the lesson material and instruction on paragraph writing via Facebook while assessing students' writing along with constructive feedback in the same way. Moreover, the students employed the Facebook group to share their work with the entire group including the teacher, correct the work of their peers, and exchange their feedback on each other's work. After the relevant period, the group of participants assembled in a traditional classroom situation, writing paragraphs by means of the paper-based method. Thus, they were facilitated to compare the Facebook environment and the traditional classroom environment and were expected to provide their feedback on the two types of ESL settings. The findings achieved through a review of their responses to the two respective pedagogical settings, online via social media and classroom with physical amenities and resources, reveal that learning via a Facebook group has benefits in terms of boosting confidence, intensifying motivation, and promoting connected learning, despite a few challenges concerned with distractions and technical problems. Moreover, the results suggest Facebook as an innovative learning setting that is appealing, motivating and full of social interactions which are incredible in comparison to traditional teaching practices. The findings of the study may help ESL educators in incorporating Facebook into their teaching repertoire.
University of ColomboInstitute of Agrotechnology and Rural Sciences (UCIARS) Diggahakoratuwa, Karaputugala, Kamburupitiya

dilini.jayarathna95@gmail.com https://orcid.org/0000-0002-8065-1318

Keywords:Facebook groups, Online learning, Paragraph writing skills, Social Media Networks, Virtual classrooms

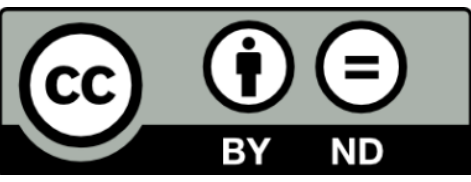

This article is published under the Creative Commons CC-BY-ND License (https://creativecommons.org/licenses/by-nd/4.0/). This license permits to use, distribute, and reproduce the contents of the publication for commercial and non-commercial purposes, provided that the original work is properly cited and is not changed anyway. 


\section{INTRODUCTION}

Educators have recently viewed online teaching and learning sites as productive methods for ESL teaching. Thus, according to Hoadley et al. (2010), social networking sites have become one of the most projecting options for interaction. Moreover, they allow people or its users to share their views, personal information and an opportunity to make novel friends, and join with new groups of people (Hew, 2011). However, among all the social networking sites such as Twitter, Instagram and LinkedIn, Facebook is considered as a highly attention-grabbing site (Raza, Qazi \&Umer, 2017). Founded and launched by the Harvard student Mark Zuckerberg in 2004, Facebook is currently the major social networking service with over 2.7 billion active users monthly as of the second quarter of 2020 (Clement, 2020).

Furthermore, it is considered a contentious matter to use social media networks such as Facebook in teaching. Facebook offers ample opportunities for language learning, whereas users have the ability to share educational knowledge within the community settings of Facebook, especially through Facebook groups. Facebook has the potential for teaching and learning as it facilitates the community between teachers and students (Mazman\&Usluel, 2010). Mohamad \& Mohamad Shariff (2011) demonstrates that Facebook-based learning has augmented students' understanding and motivation. Students are able to improve their English paragraph writing skills and knowledge not only from the in-class instruction but also from cooperative learning. Thus, the Facebook integrated instruction significantly enhances students' interest and enthusiasm for learning. In contrast, the educational application of Facebook has gained certain criticism from scholars. According to Cassidy (2006), there are considerations about its implementation mainly because it distracts users from learning. Besides, the unreliability of the information shared on the platform is problematic (Tang et al., 2015). Therefore, the teaching and learning process through Facebook has got diverse perceptions and attitudes over the time.

Moreover, as writing skills facilitate students to communicate, learn or express creativity, teaching writing gains a significant position in the language teaching repertoire. Hence, writing is often considered as the most difficult skill out of the four language skills for second language learners to acquire (Richards \&Renandya, 2002). Thus, it is noticeable that most of the students lack competence in English writing skills which are highly assessed in language tests.

\section{Research problem}




\section{Original Article}

DOI: http://doi.org/ 10.4038/jsshr.v6i1.51

Tertiary level ESL learners frequently encounter certain complications in mastering paragraph writing skills. AlGhussain's study (as cited in Al-Haj, 2015) affirms that many complaints are raised by language teachers regarding students' low levels in writing; both in mother tongue and in English as a foreign language. The present study focuses on paragraph writing skills because it is significant for the Sri Lankan tertiary level ESL learners as an expressive tool that enables them to communicate their ideas perfectly and fluently. However, the prevalence of Facebook and its plentiful prospects have raised debatable views among scholars on applying Facebook to education. In Sri Lanka, while the number of Facebook users is higher than other social media, research on this platform remains remarkably insufficient and mostly limited within educational perspectives. Correspondingly, while the country is struggling to advance its longcriticized traditional education system and apprehend into global inclinations of assimilating new technologies into teaching, there is a gap of understanding on the perceptions of students towards utilizing social networking sites for education. Therefore, this study was intended to conduct as a further investigation on perceptions of students who study English as a Second Language (ESL) on the efficacy of using Facebook groups as a medium for learning paragraph writing skills in the Sri Lankan context.

\section{Research Questions}

The following research questions were posed in order to investigate the capability of Facebook groups in aiding paragraph writing as a means of developing writing skills.

1. What are the advantages of learning paragraph writing through a Facebook group?

2. How paragraphwriting skills could be improved through a Facebook group?

3. What can be considered as challenges of learning paragraphwriting through a Facebook group?

\section{Objectives of the Research}

Facebook groups are considered as platforms where students gain more interaction and opportunities to write. Thus, one objective of this research is to identify whether the implementation of Facebook groups has benefits for the ESL students with their paragraphwriting skills. Additionally, the other objective of the current study is to determine the challenges that the students face in relation to learning paragraph writing via the Facebook groups.

\section{Significance of the Study}

The significance of using Facebook groups in developing ESL learners' writing skills appears as a beneficial recommendation; where the application of this strategy may facilitate them in employing writing skills into daily writing activities such 


\section{Original Article}

DOI: http://doi.org/ 10.4038/jsshr.v6i1.51

as paragraphs to become effective communicators via writing. As a matter of fact, the Sri Lankan education system has gained criticism for its rigidness, teacher-centralization and impracticality. Mostly, "the teaching practices in the universities are teacher-centered learning approach (TCL)" where the "lecturer provides structured materials during lectures, while students listen and take notes" (Rasika, 2018, p.2). Thus, the tertiary education in Sri Lanka is in a state of crisis due to the disparities in access to quality education, the lack of responsiveness of the education system to labour market requirements and the lack of technical education or vocational trainings (Gnanawasa, 2017). Therefore, the understanding on learners' perceptions is vital for educators in adopting an innovative language teaching platform such as Facebook to solve prevailing issues in the teaching sphere in Sri Lanka. Additionally, the present study is significant to the field due to the absence of prior research studies about examining students' perceptions on incorporating Facebook groups to teach paragraphwriting skills for tertiary level ESL learners at the University of Kelaniya.

\section{LITERATURE REVIEW}

\section{Theoretical Framework}

In terms of learning, Facebook promotesKrashen's Affective Filter Hypothesis and Monitor Hypothesis.
According to Krashen, there are five hypotheses in the theory of second language acquisition. They are acquisition and learning hypothesis, natural order hypothesis, monitor hypothesis, input hypothesis and affective filter hypothesis (Krashen, 1985). Among them, affective filter hypothesis is considered as an important factor that affects second language learning in a classroom. Krashen defines affective filter as a mental block that prevents learners from fully using the comprehensible input. Moreover, he states that the input will not reach the language acquisition device if the learner has no motivation, self-confidence and anxiety. Thus, the effect of these three factors should be reduced in order to make the learners acquire the target language in a second language classroom effectively. Therefore, if the affective filter is high, the language learner will consider the classroom to be a space where his weaknesses will be visible and if the affective filter is low, the learners consider themselves as potential members in the language classroom (Krashen, 1985).

Besides, motivation holds an influential position in the language classroom. Gardner (1985) defines motivation to learn an L2 as the extent to which the individual works or strives to learn the language because of a desire to do so and the satisfaction experienced in this activity. Thus, the motivation of Second Language Learning (SLA) refers to the impetus 


\section{Original Article}

and the desire of the acquirers. Moreover, Du (2009) states that motivation is "the most important factor in language learning, without which even gifted individuals cannot accomplish long-term goals, whatever the curricula and whoever the teacher is" (p.162). Therefore, it is vital to increase motivation and reduce anxiety to make the language acquisition process successful. Hence, a popular social media such as Facebook can be used as the source of language input to increase students' motivation to learn. In relation to this theory, Facebook creates a nonthreatening learning environment with less social pressure and lowering the affective filter to enhance the comprehensible input in language learning (Suthiwartnarueput and Wasanasomsithi, 2012). Moreover, the ability to avoid face-to-face interaction lowers the learners' level of anxiety (Murphy, 2008). Therefore, such a learning style can reduce the Affective Filter and eventually enhance motivation and risk-taking in language learning (Krashen, 1985). Therefore, in this study, Facebook is employed as a motivational tool to develop paragraph writing skills of ESL learners.

Furthermore, the Monitor Hypothesis formulated by Krashen (1985) emphasizes that the explicit knowledge about a language guides the learner to monitor the language output while correcting and editing it. According to McLaughlin (1987), "the monitor is thought to alter the output of the acquired system before or after the utterance is actually written or spoken, but the utterance is initiated entirely by the acquired system" (p. 24). Therefore, the Monitor Hypothesis is applicable when there is enough time to perform in writing if the students have linguistic familiarity with language forms and structures. Thus, in the present study, the adult learners get the opportunity to engage in self-monitoring process by analyzing and comparing language structures that they use to write paragraphs because the learners have sufficient time to reread, think, reflect and rewrite.

\section{Previous Research}

Facebook, being the second most visited website in the world and the most visited in Sri Lanka, could be identified as a special source of influence. Today, an average user browses Facebook at least for 30 minutes a day as a habit of using computers or smart devices and gets exposed to diverse content on Facebook (Andreassen et al., 2013; Griffiths, 2012). The majority of users (77.2\%) belong to age 18-27 which means that the young generation in Sri Lanka is much engaged in Facebook (Rathnayake, 2018). Regarding that, incorporating social media sites to the curriculum can be functional in language teaching, especially Facebook which allows users to exchange photos, profiles and videos with others (Terantino\& Graf, 2011). 


\section{Original Article}

DOI: http://doi.org/ 10.4038/jsshr.v6i1.51

According to Srirat (2014), Facebook groups are for members of groups to connect, share and collaborate on a given topic or idea while the main purpose of groups is to help Facebook users socialize around any topic or community. Moreover, as cited in Srirat(2014), O'Neill (2010) states that Facebook groups have the capability for administrators to message members of the group directly and all the members of a group have the ability to connect in a single chat window. However, Shih (2011) accounts that the students improve in paragraph organizations, content, vocabulary, spelling, and grammar after getting Facebook integrated blended learning. Moreover, Al-Shehri (2011) states that Facebook creates a positive language learning atmosphere and expand the abilities to synthesize facts and ideas. Srirat (2014) states that Facebook groups can be utilized to facilitate teaching foreign language courses more effectively. Furthermore, the study reveals that non-English majored students made quite outstanding participation in sharing, discussing and arguing in English successively via Facebook groups. Furthermore, Ghani (2015) suggests the use of Facebook as an alternative tool that can be used for teaching and learning to enhance students' interactions outside the classroom.

Additionally, Facebook provides ample prospects for students to practice and improve their writing skills (Yunus\& Salehi, 2012). Hence,
Kabilan et al. (2010) showed that, in terms of affective factors, students' confidence, motivation, and attitudes improved extensively as well as students claimed that using Facebook improved their confidence as well as made them more enthusiastic to use the language especially in terms of writing. In addition, the majority of the learners also corresponded that Facebook motivated them to read and write in English as everything is available on the Internet (Yunus\& Salehi, 2012).

Moreover, Bani- Hani, Al-Sobh and Abu-Mehim (2014) investigate the perceptions and attitudes of Jordanian EFL students at Irbid University College on utilizing Facebook groups in teaching writing. This study reveals that Facebook groups play a distinguishing role in enhancing the writing performance level and brainstorm ideas at the pre-writing stage. Furthermore, the findings uncover that the students can develop their vocabulary by being exposed to fellow group members' posts in addition to checking misspelled words. Furthermore, Rifai (2010) aims to investigate the affiliation between students' attitudes on the use of Facebook and blog as learning tools in writing class. The result shows that Facebook and blog gave a significant influence on improving students' writing competence. Correspondingly, Melor, Salehi, Sun, Yen, and Li (2012) examine the students' perceptions on the use of Facebook groups in teaching 


\section{Original Article}

DOI: http://doi.org/ 10.4038/jsshr.v6i1.51

ESL writing. The quantity of data gathered in the research is limited since the students' perceptions were measured only through a questionnaire comprising 10 closeended items. The findings denoted that Facebook groups can be effective in teaching ESL writing and the students learn new vocabulary from reading the comments of others in the group while the spell-check feature helps diminish their spelling errors.

Although the previous studies point out only the assistance of Facebook along with education, Meskill\& Quah (2013) declare that the challenge is to conceptualize, problematize and research the complex relationships that are organically arising between students and educators and the technologies they use in cyberspace.

\section{RESEARCH METHODOLOGY}

\section{Participants}

The research included a purposive sample of 30 intermediate-level ESL students from the University of Kelaniya who were studying 'English for Social Sciences' course in the first year. In addition, 'English for Social Sciences' is a mandatory course administered by the Department of English Language Teaching, University of Kelaniya for first-year undergraduates at the Faculty of Social Sciences to address all four language skills, namely listening, reading, writing and speaking. Moreover, the 30 students in the study ranged from age 21 to 23, while Sinhala was their first language (L1).

\section{Research Design}

Qualitative research design was employed in this study to collect perceptions of the ESL students towards the efficacy of using a Facebook group in teaching paragraph writing skills. All the 30 participants were required to join with a Facebook group named "Time for Writing" designed by the researcher and lessons on paragraph writing were conducted through it for six weeks. A closed Facebook group was selected for this study because the researcher, as the administrator can control admission of members to the group, students can share information related to the topic with all members in the group with one share while the posts in the group are visible only for the group members. Moreover, only the teacher had the authority to send invitations to students as the administrator of the closed Facebook group while outside members were not allowed. The posting settings of the group were changed in a way that the teacher's approval is required before posting content to the group in order to avoid violation, unnecessary content and spam. Additionally, Facebook group rules and guidelines were utilized to ensure the participant's privacy, to avoid hate speech, bullying, promotions or spam and to maintain the courtesy and respect of each participant in the group. 


\section{Original Article}

DOI: http://doi.org/ 10.4038/jsshr.v6i1.51

In order to conduct the teaching process in the Facebook group, audio clips, videos, images and charts were used while the teacher acted as the facilitator. The lessons were developed based on the 'Paragraph Hamburger Strategy' with an emphasis on the paragraph organization. Supplementary learning material and lessons on verb tenses, adjectives, transitions, capitalization, punctuation and common spelling errors were posted on the group with the aim of smoothening the paragraph writing process. Lessons were posted on every Monday, Wednesday and Saturday. Students were expected to practice and engage with lessons by commenting answers on posts continually. Hence, after each paragraph writing lesson all the participants were expected to post a fifty words paragraph on the given topic incorporating trained paragraph writing skills in the comment section. Afterwards, the researcher provided feedback on students' paragraphs by checking for their errors daily. Participants' paragraphs were marked using a rubric which allocated scores for the organization (topic sentence, supporting sentences and concluding sentence) grammar, vocabulary and mechanics (spelling, punctuation and capitalization). This process was continued with the intention of allowing students to reflect on their mistakes and to revise the written paragraphs. In order to improve the participants' engagement in the learning group, online quizzes, games, discussion forums and polls related to paragraph writing are utilized. Moreover, group insights were monitored continuously by the researcher. The most engaging students were selected and they were appreciated with the intention of improving their motivation.

Subsequently, all the participants were exposed to traditional paper-based learning in a classroom setting. For this purpose, paper-based material was used in order to teach the same paragraph writing lessons conducted via the Facebook group. Finally, semistructured interviews were conducted with ten randomly selected participants in Sinhala after the period of teaching to examine their perceptions on the Facebook integrated course.

\section{Data Collection Tools and Data Analysis}

Semi-structured interviews were conducted to obtain students' perceptions of using paragraph writing lessons in the Facebook learning group and recommendations for improving the teaching-learning process in the platform. According to Bryman (2008), this data collection method offers a flexible way of obtaining information within relative boundaries. Moreover, this strategy allows the researcher to ask additional questions to gain clarification or further information from participants' answers (Leedy\& Ormrod, 2013). The interviews were conducted face-to-face choosing ten students in the Facebook learning group randomly. The major 


\section{Original Article}

DOI: http://doi.org/ 10.4038/jsshr.v6i1.51

topics of the interview questionnaire were as follows.

1. Advantages of learning paragraph writing through the Facebook group

2. Challenges of learning paragraph writing through the Facebook group

This study adopts the method of thematic analysis to analyze semistructured interviews. First, they are recorded, transcribed using standard verbatim and translated from Sinhala to English to analyze emerging concepts, themes or conclusions. Lichtman (2006) and her explanation of "the three Cs of analysis: from Coding to Categorizing to Concepts" (p.167) served as a guide to analyze interview data. Furthermore, interviews are analyzed thematically to account for in-depth narrative description and identification of general themes along with supporting respondent quotes (Van Esch, 2013).

\section{RESULT AND FINDINGS}

The perceptions of students obtained through semi-structured interviews are presented as two sections entailing advantages and challenges of Facebook group application in language education especially in developing paragraph writing skills.

\section{Advantages of Facebook Group} Application in Language Education
From the perspective of students, using Facebook forlearning offers many benefits that may help them perform better and become active learners. The following are the advantages of using Facebook according to the students' perception.

\section{Boosting Confidence}

All five interviewees adhere to the opinion that Facebook is a source of improving confidence. Participant A admitted that Facebook groups enable students to clarify or ask questions directly from the teacher without getting feelings of nervousness or shyness because they are not exposed to the other students. Moreover, the perception of Participant E on the potential of Facebook in improving students' confidence is stated as follows.

"Students feel relaxed in Facebook education rather than asking and answering questions in front of the class" (Participant E- Translated from Sinhala).

Moreover, participants admitted that the Facebook group enhanced their confidence to write in English because they felt like that they were socializing with friends, not studying English as a separate subject. Additionally, participant $\mathrm{C}$ affirmed that students felt comfortable posting ideas or opinions as paragraphs on the Facebook learning group while they felt encouraged and appreciated when receiving friends' 'likes' and 


\section{Original Article}

'comments' on their writings. This shows that learning through a Facebook group lowers the learners' level of anxiety as it avoids face-to-face communication.

\section{Intensifying Motivation}

Shih (2013) found that integrating Facebook can enhance students' learning motivation, interest, and interaction to exchange information and share knowledge. Participant A has acknowledged that learning paragraph writing through the Facebook group supported them to increase their motivation and to memorize the lessons effortlessly better than a traditional classroom. Furthermore, the students mentioned that though they learn in classrooms using books and handouts, Facebook offers diverse opportunities to learn via videos, charts, and images that inspire them to learn, especially paragraph writing. Besides, participant $B$ declared that most of the students consider Facebook learning is enthusiastic and fruitful rather than their usual monotonous classrooms. Participant C proclaimed that Facebook automatically persuades its regular users to learn writing skills and it provides prospects to self-study a language as well.

\section{Feasibility of Use}

All the interviewees affirmed that Facebook is easy to use, unproblematic and familiar while it has a visually pleasing interface justifying its adoption in language education. Participant A declared that learning via the Facebook group is effective than a traditional classroom. The students further added that they were able to learn paragraphwriting through the Facebook group successfully because there was no exact limited learning time in it alike regular classrooms of two or three hours. Thus, the students were able to learn paragraph writing via Facebook in a flexible way. The opinion of the participant $B$ is as follows.

"Learning in a classroom is inflexible because we are given a specific time and a place to learn. Nonetheless, learning through the Facebook group is different as we can learn while we are at home, when travelling, when we go to bed and everywhere." (Participant $B$ - Translated from Sinhala)

Moreover, participant acknowledged that Facebook allowed them to study a lesson step by step and provided sufficient time to grasp the lesson. Additionally, participant $\mathrm{H}$ revealed that they are able to learn paragraph writing with the resources on the Facebook group even though a teacher is not available. Hence, it is evident that Facebook promotes autonomous learning while making progress in paragraph writing skills.

"When we check the FB group, we can refer back to the lessons that we missed. In the classroom, we miss the lesson if we get absent on that day. But the situation is different in using 


\section{Original Article}

Facebook." (Participant D- Translated from Sinhala)

Furthermore, participant E stated that they got quick feedback after commenting answers on the Facebook posts making them identify their errors without delay.

"We got quick feedback for our writing on the Facebook group, but in a classroom, we have to wait for the next class to get feedback on our writing." (Participant E- Translated from Sinhala)

Therefore, the students have identified that Facebook is a new trend in teaching-learning process except gossiping and watching memes on social media.

\section{Promoting learning}

All the participants agreed that the Facebook group was helpful in accessing or sharing educational resources related to paragraph writing. Participant A acknowledged the convenience of accessing and sharing rich multimedia resources through Facebook, which subsequently improved their learning experience.

"I think Facebook is not only convenient for entertainment but it also brings me various opportunities to share educational materials and improve my paragraph writing skills" (Participant A- Translated from Sinhala)
Moreover, participant $\mathrm{D}$ affirmed that they learnt new vocabulary from reading the comments of others in the group while the spell-check feature helped diminish their spelling errors in paragraph writing.

"When typing answers on the
Facebook group we got word
suggestions on our devices. So, it
reduced our spelling mistakes."
(Participant E- Translated from
Sinhala)

In addition, Facebook groups enhance peer learning which is more effective than individual learning. According to participant $C$, the opinions by peers helped them in getting better ideas for writing and they also find it easier to complete their paragraphs after participating in the Facebook group discussions. Moreover, participant A mentioned that the Facebook group enabled them to see their peers' writings as comments on Facebook as well as the feedback comments for them by the teacher. This promoted self-reflection and self-regulation of the learners while they discovered that mistakes are elements of the process of learning. In a traditional classroom context, usually students do not get an opportunity to view others' pieces of writing and the relevant feedback by the teacher. Thus, the participants have claimed that they were able to expand their vocabulary and grammar through the Facebook group used in the study. This situation has motivated the learners to practice paragraph writing well because they visualized 


\section{Original Article}

learning as an authentic process among their peers. Therefore, participant $\mathrm{J}$ stated that when his friends wrote well in English, he felt that he also should practice more and more.

\section{Challenges of Facebook Group} Application in Language Education

From the perspective of students, using a Facebook group forlearning has some drawbacks. The following are the challenges of using Facebook according to the students' perception.

\section{Distraction}

According to the interviewed students, the distraction by other content on Facebook such as memes, gossips, friend requests, and notifications is a disadvantage of using Facebook for education. Most of the interviewees have also emphasized losing concentration while performing studyrelated activities on the Facebook group.

"Users can be distracted or carried out with the gossips and memes they see on the News Feed. When we are online it's our habit to check out who likes and comments on our posts. And we usually check out to see what our Facebook friends are doing. So, it can make us inattentive and forget the actual educational tasks to do." (Participant A- Translated from Sinhala)

Moreover, participant $\mathrm{C}$ affirmed that the students watched educational posts on Facebook but they failed to practice paragraph writing because they ended up surfing on different non-educational things for several hours. Additionally, participant E stated that they were perhaps disturbed by other conversations from friends and groups because Facebook allows having more than one conversation simultaneously. On the contrary, some interviewees reflected the tricks they employed to confront Facebook distractions through their News Feed page and personal conversations. Especially, participant $\mathrm{C}$ and D intentionally avoided surfing on the News Feed as much as possible. Participant E mentioned that when surfing on Facebook, they tried to first check out important features such as notifications, inbox and posts from the learning groups to avoid losing focus.

\section{Technical Problems}

Interviewees raised technical problems as a difficulty when using Facebook for educational purposes. For example, participant B claimed that unstable internet connection disrupted while studying and practicing writing lessons on the Facebook group. Moreover, the sudden loss of electricity was another issue they faced while engaging with lessons on the Facebook group. In addition, participant E mentioned that on some occasions they did not receive notifications when lessons are posted on Facebook. Furthermore, participants stated that students who do not have high competence in 


\section{Original Article}

DOI: http://doi.org/ 10.4038/jsshr.v6i1.51

relation to technical skills may not cooperate frequently with lessons conducted using Facebook. Thus, students who are not confident about managing their privacy settings are less tended to collaborate in the setting of Facebook.

\section{Other Minor Difficulties}

Participants acknowledged that perhaps the application of Facebook in education led to the inevitable mixing of personal and study life, making learners annoyed and uncomfortable. Additionally, ineffective management of information such as receiving too many posts from different groups, mixing up old and new posts while facing difficulties in retrieving old posts can be considered as other minor challenges of using a Facebook group in developing ESL learners' paragraph writing skills.

\section{DISCUSSION}

The findings obtained from the students' regarding their perceptions on learning English writing skills on Facebook as an online learning environment revealed both positive and negative effects.

Boosting confidence, intensifying motivation, the feasibility of use and promoting connected learning emerged as the advantages of using a Facebook group to improve paragraph writing skills of tertiary level ESL learners. First, Facebook is valued for boosting confidence among learners rather than a traditional classroom. Similarly, McCarthy (2010) states that students can interact and communicate in an online environment at their own pace and take time to consider comments and responses rather than being anxious or embarrassed, as in the physical classroom. In addition, Facebook increases motivation, self-confidence and enhance students' achievement by affecting students' attitude and helping them feel more independent (AbuSa'aleek, 2016).

Secondly, Facebook is appreciated by the participants for improving motivation in language learning, especially in paragraph writing. Correspondingly, Blattner \& Fiori (2009) state that Facebook can be utilized to improve students' performance of the English language, increase motivation and generate authentic language interaction.

Thirdly, a prominent advantage of Facebook acknowledged by students is the feasibility of use. This finding corroborates with Akbari et al. (2012) who discovered Facebook has great potential as an effective formal educational tool for language learning. Moreover, FB has "unique features that offer constructive educational experiences while maintaining privacy and safety" and that the potential of Facebook is "growing every day with new applications" (Blattner \& Fiori, 2009, p.8). Additionally, Facebook is regarded for enhancing interpersonal collaboration and peer support among 


\section{Original Article}

DOI: http://doi.org/ 10.4038/jsshr.v6i1.51

learners by offering them a userfriendly platform to get engaged and operate group work, resembling what Manasijevic et al. (2016) and McCathy (2010) have found from their research.

Lastly, Facebook is considered to be an effective tool in promoting learning. In similar studies, it is confirmed that Facebook has facilitated students' language learning, made a more collaborative class environment and even motivated them to learn (Seitzinger, 2006; Pinkman, 2005; Abu Bakar, 2010; Bakar, 2009). Additionally, students considered Facebook as an innovative learning setting which provided them a novel experience in learning English writing. Thus, Moon (2011) found that Facebook builds a positive language learning atmosphere and develops the abilities to synthesize ideas and facts from various sources of information.

However, the present study determined the common challenges students encounter when using Facebook for educational purposes. Initially, the most evident disadvantage informed by many students is distraction. As originally designed for socializing and entertainment purposes, Facebook provides far more functions than those desirable for learning which users have hardly full control over. Hence, while using Facebook with educational goals in mind, students are easily distracted and carried away by irrelevant content, verifying findings from previous studies by Coklar (2012) and Wise et al. (2011).

Additionally, technical issues appeared as a practical problem confronting the use of Facebook for education. Students might face unavoidable technical breakdowns that they normally have only minimal control over. Some other undergraduates had difficulty in retrieving previous posts or get frustratingly targeted by spams or irrelevant posts confirming results Nguyen (2017) has proposed. Therefore, the findings emerged in the present study are congruent with previous research studies that investigated the use of Facebook or Facebook groups as tools for enhancing students' language learning skills in pedagogical settings.

\section{CONCLUSION}

Significantly, the students had many positive attitudes towards Facebook based learning than negative opinions. In their opinion, Facebook was an alternative and innovative learning tool which was easily accessible for them. This offered the students flexibility and more opportunities to learn the English language, thereby improving their paragraph writing skills. They managed to overcome their nervousness and be confident to ask questions or clarifications by the teacher via Facebook rather than in a traditional classroom. Additionally, Facebook enhanced ESL learners to be 


\section{Original Article}

DOI: http://doi.org/ 10.4038/jsshr.v6i1.51

independent in practicing different methods of writing paragraphs on the Facebook page utilized for this study while boosting self-learning. Therefore, these findings support the theoretical framework of the study namely Affective Filter Hypothesis and Monitor Hypothesis because Facebook enhanced language learning lowering the affective filter while providing prospects for effective learning and it promoted self-learning by engaging in a self-reflection process. Furthermore, this study offers evidence to fill the knowledge void in understanding learners' perceptions on social media such as Facebook in relation to education within the Sri Lankan context.

\section{Limitations}

A limitation in this study laid in the application of semi-structured interviews which could generate biased opinions. Thus, this limitation might affect the possibility of generalizing the research results. Despite this limitation, this study exposes positive outcomes of using Facebook for teaching paragraph writing skills for tertiary level ESL learners.

\section{Implications}

Whereas Facebook is not always used in universities as an official learning tool, undergraduates are using it for a wide range of educational purposes, including communication, collaboration, and sharing academic materials. The already popularity of Facebook and the largely positive mindset of the undergraduates towards it reflect the significant potential to rely on Facebook in higher education deserving the attention of educators.

Correspondingly, Farris-Berg (2005) emphasized that digital natives appreciate the use of Internet-based resources in their classes and progressively want to employ technology to learn.According to Blattner and Lomicka (2012), teachers need new strategies and resources to grab students' attention considering their thinking patterns and socializing behaviours stimulated by the use of the Internet. Hence, Facebook is able to engage learners in language-based activities, in spite of its original intention of socializing. Facebook has the potential to carry on a course unit independently or to complement a language course as an instructional supplement under the supervision of teachers. Furthermore, using Facebook groups is beneficial for real language interaction and the development of social-pragmatic knowledge that is frequently missing in course books or textbooks. On such occasions, educators should change their dominating and advising roles for benefactors, organizers, participants, mentors, and researchers. Therefore, Sri Lankan universities should adopt Facebook for enhancing the paragraph writing skills of students as the use of new technology for learning becomes 
a trending scenario in universities and colleges worldwide.

In conclusion, the educational use of Facebook in higher-educational environments appears as a trendy and effective practice rather than traditional classrooms because it has diverse benefits for both learners and educators. It is recommended that further research could focus more on the overcoming challenges of integrating Facebook groups for teaching paragraph writing. Since the present study was conducted with a limited number of participants, it is recommended that future researchers conduct more large-scale empirical research on latent variables for deeper examination. Besides, as teachers play a decisive role in the teaching-learning process, it is important to examine the perceptions of teachers about using Facebook in their professional practices.

\section{References}

Abu B. N., \& Latif, H. (2010). ESL students' feedback on the use of blogs for language learning. 3L: Language, Linguistics, Literature, 16(1), 120-141.

AbuSa'aleek, A.O. (2016). Students' perceptions of English language learning in the Facebook context. Teaching English with technology, 15(4), 60-75.

Akbari, E., Naderi, A., Aliabadi , Z. A., Simons, R.-J., \& Pilot, A. (2012). Increased motivation in language learners through social networks. International Conference- ICT for Language Learning, 1-4. Retrieved from https://pdfs.semanticscholar.org/4c6b/11 30e6d634472eb44ac7d148385d4817c 551.pdf
Al-Shehri, S. (2011). Connectivism: A new pathway for theorizing and promoting mobile language learning. International Journal of Innovation and Leadership on the Teaching of Humanities, 1(2), 10-31.

Andreassen, C. S., Griffiths, M. D., Gjertsen, S. R., Krossbakken, E., Kvam, S., and Pallesen, S. (2013). The relationships between behavioral addictions and the five-factor model of personality. Journal of Behavioral Addictions, 2(2), 90-99.

Bakar, N.A. (2009). E-learning environment: Blogging as a platform for language learning. European Journal of Social Sciences, 9, 594-604.

Bani-Hani, N. A., Al-Sobh, M. A., \& AbuMelhim, A.-R. H. (2014). Utilizing Facebook groups in teaching writing: Jordanian EFL students' perceptions and attitudes. International Journal of English Linguistics, 4(5), 27-34.

Blattner, G., \& Fiori, M. (2009). Facebook in the language classroom: Promises and possibilities. International Journal of Instructional Technology and Distance Learning, 6, 17-28.

Blattner, G., \&Lomicka, L. (2012). Facebooking and the social generation: a new era of language learning, Alsic, 15(1),1-36.

Bryman, A. (2008). Of methods and methodology. Qualitative Research in Organizations and Management: $A n$ International Journal, 3(2), 159-168.

Cassidy, J. (2006, May 15). Me Media. The New Yorker. Retrieved from http://www.newyorker.com/magazine/2 006/05/15/me-media

Clement J. (2020). Number of monthly active Facebook users worldwide as of 3 rd quarter 2020 (in millions). Facebook Statistics. Retrieved from: Facebook MAU worldwide 2020 | Statista

Çoklar, A. N. (2012). Evaluations of students on Facebook as an educational environment. Turkish Online Journal of Qualitative Inquiry, 3(2), 42-53.

Du, X. (2009). The Affective Filter in Second Language Teaching. Asian Social Science, $5(8), 62$ 
Farris-Berg, K. (2005). Listening to student voices on technology: Today's tech savvy students are stuck in textdominated schools. Saint Paul, MN: Education Evolving. Retrieved from http://www.educationevolving.org/pdf/t ech_savy_students.pdf

Gardner, R. C. (1985). Social psychology and second language learning: The role of attitudes and motivation. London: Edward Arnold.

Ghani, M. B. A. (2015). Using Facebook in Teaching and Learning English. The International Conference on Language, Literature, Culture and Education.97- 102. Retrieved from https://icsai.org/procarch/2icllce/2icllce92.pdf

Gnanawasa, M. (2017). A study of a few recognized educational issues faced by Sri Lanka at present, Fourth Asia Pacific Conference on Advanced Research (APCAR), (pp.35-42), Melbourne. Retrieved from https://apiar.org.au/wpcontent/uploads/ 2017/04/6_APCAR_MAR_2017_BRR739_ education-35- 42.pdf

Hew, K. F. (2011). Students' and teachers' use of Facebook. Computers in human behavior, 27(2), 662-676.

Hoadley, C. M., Xu, H., Lee, J. J., \&Rosson, M. B. (2010). Privacy as information access and illusory control: The case of the Facebook News Feed privacy outcry. Electronic commerce research and applications, 9(1), 50-60.

Kabilan, M. K., Ahmad, N., \& Abidin, M. J. Z. (2010). Facebook: An online environment for learning of English in institutions of higher education. The Internet and Higher Education, 13(4), 179187. Retrieved from https://www.academia.edu/831665/Face book_An_online_environment_for_le arning_of_English_in_institutions_of_hi gher_education

Krashen, S. (1985). The input hypothesis: Issues and implications. New York: Longman.
Leedy, P. D., \& Ormrod, J. E. (2013). Practical research: Planning and design (5th ed.). Upper Saddle River, NJ: Pearson.

Lichtman, M. (2006). Qualitative research in education: A user's guide. London: Sage Publications.

Manasijević, D., Živković, D., Arsić, S., \&Milošević, I.(2016). Exploring students' purposes of usage and educational usage of Facebook. Computers in Human Behavior, 60, 441-450. Retrieved from https://doi.org/10.1016/j.chb.2016.02.087

Mazman, S. G., \&Usluel, Y. K. (2010). Modeling educational usage of Facebook. Computers $\mathcal{E}$ Education, 55(2), 444- 453.

McCarthy, J. (2010). Blended learning environments: Using social networking sites to enhance the first year experience. Australasian Journal of Educational Technology, 26(6), 729-740.

McCarthy, J. (2010). Blended learning environments: Using social networking sites to enhance the first year experience. Australasian Journal of Educational Technology, 26(6), 729-740.

Melor, M. D. Y., Salehi, H., Sun, Ch. H., Yen, J. Y. P., \& Li, L. K. S. (2012). Using Facebook groups in teaching ESL writing, Recent Researches in Chemistry, Biology, Environment and Culture, 75(1), 75-80.

Meskill, C. \& Quah, J. (2013). Researching language learning in the age of social media. In H. R. Michael Thomas (Eds.), Contemporary Computer-Assisted Language Learning (pp.39-52). London: Bloomsbury Publishing Plc.

Mohamad, R., \& Mohamad Shariff, S. (2011). Effect of Social media usage on discussion approach in teaching and learning of history subject. JurnalTeknologi Pendidikan, 1(1), 75-80.

Moon, A. L. (2011). The impact of Facebook on undergraduate academic performance: Implications for educational leaders. Michigan: Central Michigan University.

Murphy, J. M., \& Leighton, A. H. (2008). Anxiety: its role in the history of 
psychiatric epidemiology. Psychological Medicine, 39(07), 1055.

Nguyen, T. (2017). Undergraduate students' use of Facebook for educational purposes: Advantages, difficulties, and potential for connected learning (Master thesis). Retrieved from https://trepo.tuni.fi/bitstream/handle/10 024/102580/1513684873

Pinkman, K. (2005). Using blogs in the foreign language classroom; Encouraging learner independence. The JALT CALL Journal, 1(1), 12-24.

Rasika, D.G.L. (2018). Student Centered Curriculum A higher education case study in Sri Lankan university system, Conference: Creating a sustainable lens for higher education (pp.1-24), Bangalore, India. Retrieved from https://www.researchgate.net/publicatio $\mathrm{n} / 328930009$

Rathnayake, T., \&Rathnayake, D. (2018). Facebook Usage of Sri Lankan Consumers: Consumption Perspective of Social Media. Arts and Social Sciences Journal, 09(04), 337-341.

Raza, S. A., Qazi, W., \&Umer, A. (2017). Facebook Is a Source of Social Capital Building Among University Students: Evidence From a Developing Country. Journal of Educational Computing Research, 55(3), 295-322.

Richards, J.C. \&Renandya, W. (2002). Section 13: Teaching writing. In J.C. Richards and W. Renandya (eds.). Methodology in language teaching: An anthology of current practice (pp.303-305). Cambridge: Cambridge University Press.

Rifai, I. (2010). Students' attitude on the use of Facebook and blog in writing class and their writing competence. Lingua Cultura, 4(1), 25-38.

Seitzinger, J. (2006). Be constructive: Blogs, podcasts, and wikis as constructivist learning tools. Learning solutions emagazine, 1-14. Retrieved from https://www.researchgate.net/profile/Jo yce_Seitzinger/publication/200772664 _Be_constructive_Blogs_podcasts_and_ wikis_as_constructivist_learning_tool s/links/0f31752d5e86b2970d000000.pdf

Shih, C. R. (2011). Can Web 2.0 technology assist college students in learning English writing? Integrating Facebook and peer assessment with blended learning. Australasian Journal of Educational Technology, 27(5), 829-845.

Shih, C. R. (2013). Effect of using Facebook to assist English for business communication course instruction. The Turkish Online Journal of Education Technology, 12(1), 52-59.

Srirat, K. (2014). Using Facebook group to facilitate teaching English for everyday communication. The 2014 WEI International Academic Conference Proceedings, 5-10. Retrieved from https://www.westeastinstitute.com/wpc ontent/uploads/2014/07/Kesinee-SriratFull-Paper.pdf

Suthiwartnaruput, T. \&Wassanasomsithi, P. (2012). Effects of using Facebook as a medium for discussions of English grammar and writing of low intermediate EFL students, Electronic journal of foreign Language teaching, 9(2), 194-214. Retrieved from https://pdfs.semanticscholar.org/f4eb/1ef 06069be59621005dc02bc7d4baa0734 03.pdf

Tang, J. K. T., Yau, H.-N., Wong, S.-F., \& Wong, S.-K. (2015). The impacts on learning via social media: A study on post-secondary students in Hong Kong. Communications in Computer and Information Science Technology in Education. Technology-Mediated Proactive Learning, 195-208. doi: 10.1007/978-3662-48978-9_19

Terantino, J. \& Graf, K. (2011). In the classroom: Using Facebook in the language classroom as part of the net generation curriculum. The Language Educator, 44-47. Retrieved from http://actfl.org/files/TLEsamples/TLE/_N ovember11_Articlepdf

Van Esch, P. \& Van Esch, L. J. (2013). Justification of a qualitative 


\section{Original Article}

methodology to investigate the emerging concept: The dimensions of religion as underpinning constructs for mass media social marketing campaigns. Journal of Business Theory and Practice, 1(2), 214-243.

Wise, L.Z., Skues, J. \& Williams, B. (2011). Facebook in higher education promotes social but not academic engagement. In G. Williams, P. Statham, N. Brown \& B. Cleland (Eds.), Changing Demands, Changing Directions. Proceedings Ascilite Hobart 2011. (pp.1332-1342). Wrest point: Australia.

Yunus, M. \& Salehi, H. (2012). The Effectiveness of Facebook Groups on Teaching and Improving Writing Students Perceptions. International Journal of Education and Information Technologies, 6(1), 87-96. 